\title{
AC 2009-1731: WATER/WASTEWATER TECHNICIAN TRAINING INSTITUTE: THE FIRST YEAR RETROSPECTIVE
}

\section{Christal Wade, Western Kentucky University}

Ms. Wade holds a Master of Science Degree in Biology from Western Kentucky University. She began working in the WATERS Laboratory as an undergraduate in 2004 and accepted full-time employment as a laboratory analyst upon graduation in 2006. Ms. Wade currently holds certification under the Kentucky Microbiological Laboratory Certification Program and is an EPA Approved Principal Cryptosporidium Analyst under the Long-Term 2 Enhanced Surface Water Treatment Rule. She manages both the Microbiological and Cryptosporidium programs at the WATERS Lab. Ms. Wade also provides outreach and education for water/wastewater operators in the form of Continuing Education Unit lectures. She has prepared and delivered lectures on the Long-Term 2 Enhanced Surface Treatment Rule, the Disinfection By-Products Rule, the Total Coliform Rule, basic laboratory procedures for both water and wastewater, and waterborne pathogens. Ms. Wade delivers the lectures at training events coordinated by Kentucky Rural Water Association, Kentucky Water and Wastewater Operator's Association, West Virginia Rural Water Association, as well as public water/wastewater systems. In addition, Ms. Wade has prepared the class content for the first class of the Water/Wastewater Technician Training Institute, WTTI200C, entitled Water Supply and Wastewater Control, for which she is currently the instructor of record. Other educational experiences include Regional Science Fair Judge, preparing content and proctoring events for Science Olympiad, and preparing content and teaching classes for Girls in Science.

\section{Andrew Ernest, Western Kentucky University}

Dr. Ernest earned a B.S. and M.S. in Civil Engineering from the University of Southwestern Louisiana in 1985 and in 1986 respectively, and a Ph.D. in Civil Engineering from Texas A\&M University in 1991. He has over 16 years of professional experience in Environmental and Water Resource engineering, having managed a variety of organizational units with varying missions, encompassing consulting, academic, revenue-driven, research and service activities. Dr. Ernest currently serves as the Director of the Center for Water Resource Studies and the Associate Dean of the Ogden College of Science and Engineering at Western Kentucky University, is a Principal Engineer with Ernest and Sons Civil and Environmental Engineering consultants and a proponent of the principles of Open Engineering. He serves on Kentucky's Environmental Quality Commission, the Kentucky Board of Certification for Wastewater System Operators and a variety of other local, state and regional committees. He is a licensed engineer in Kentucky and Texas, and is a Board Certified Environmental Engineer through the American Academy of Environmental Engineers, with specialty certification in Water and Wastewater.

\section{Jana Fattic, Western Kentucky University}

Jana Fattic is the Associate Director of the Center for Water Resource Studies and Operations Director of the WATERS Laboratory at Western Kentucky University. Ms. Fattic's role as Associate Director of the Center includes budget development and project coordination of state and federal grants totaling over one million dollars annually. Ms. Fattic's responsibilities include day-to day administration, budget and personnel management, quality assurance and quality control, and maintenance of certifications. She holds a Bachelor of Science degree from Western Kentucky University, and has worked in both the public sector as a regulator and private sector as an environmental consultant prior to being employed by the Center.

\section{Karla Andrew, Western Kentucky University}

Karla Andrew is currently employed by the Center for Water Resource Studies at Western Kentucky University (CWRS WKU) as the Information Technology Manager. Her primary responsibilities include but are not limited to: managing student workers in the area of 
Information Technology tool development and research; coordinating Geographic Information Systems development; coordinated web and applications development; assisting drinking water and wastewater utilities with information technology issues that arise; providing technical assistance to water districts; and supporting the information technology needs within CWRS. Ms. Andrew has over 20 years of computer experience with the most recent 8 years being in the hydrology area. Previously Ms. Andrew worked at the Illinois State Water Survey and focused on database programming for Hydrological Models. Work included management strategies for flood protection in the Lower Illinois River (developing an interface to use the UNET Model for Real-time Simulation of Flooding), work on water quality issues within the Fox River, hydrologic modeling of climate scenarios for two Illinois watersheds, and served as Co-PI on a project involving flow forecasting for the Stratton Dam in northern Illinois. She also coordinated programming for the evaluation of the Illinois stream flow gauging network, effective discharges of Illinois streams, the Illinois Stream Flow Assessment Model (ILSAM), and data management tools for water sampling data (IDAPP). 


\title{
Water/Wastewater Technician Training Institute: The First Year Retrospective
}

\begin{abstract}
The Center for Water Resource Studies and the Bowling Green Community College of Western Kentucky University formed a partnership to address an anticipated Water \& Wastewater Operator/Technician shortage over the next five to seven years. The Water and Wastewater Technician Training Institute (WTTI, pronounced "witty"), is a joint initiative with the employment sector (a number of water \& wastewater utilities/municipalities/districts), state primacy agencies and technical assistance/trade associations to refine an industry needs driven curriculum that utilizes on-line course delivery to provide options for both traditional \& nontraditional students. This partnership was presented at the 2008 ASEE annual conference. This paper will review the accomplishments and the lessons learned by this program over the first year of operation.
\end{abstract}

The partnership has revitalized an existing Associates Degree program entitled "Water Utilities Management". The program requires sixty-seven (67) credit hours, including twenty-five (25) hours of General Education Requirements, twenty-one (21) hours of Business Technology Core courses, and (21) twenty-one hours of Operations Track courses. The Operations Track courses can be focused toward either Water or Wastewater Operations. The program is designed to be delivered entirely online, allowing students to pursue their degree with unparalleled flexibility. According to the U.S. Department of Education, in 2006-07, there were approximately 11,200 college-level programs that were designed to be completed totally through distance education; 66 percent of these programs were reported as degree programs and the remaining 34 percent were reported as certificate programs. Asynchronous internet-based technologies were cited as the most widely used technology for the instructional delivery of distance education courses; they were used to a large extent in 75 percent and to a moderate extent in 17 percent of the institutions that offered college-level credit-granting distance education courses 6 .

The WTTI courses are delivered through an open-source Course Management System (CMS) known as MOODLE (Modular Object-Oriented Dynamic Learning Environment). The first Operations Track class, entitled Water Supply \& Wastewater Control was offered/developed during the Fall semester 2008. This first course, as well as a second course entitled Water Distribution and Wastewater Collection Systems will be available during the Spring semester 2009. As courses are developed, approval is sought for Continuing Education/Contact Hours from Operator Certification Boards in the individual states. Academic content is being provided by core university faculty with support from adjunct faculty eligible staff. All instructors (academic and practitioner) involved in the program are undergoing collaborative professional development to ensure that they are receptive to the unique structure of the program.

As a demonstrably functional framework is being put in place, the program is being extrapolated to address other regional policy, academic discipline and industrial sector issues beyond the initial Kentucky and Tennessee target area. University-offered Water and Wastewater Operator Certificate Programs are being developed to fast-track students into the industry and allow current operators to reach advanced certification levels at an accelerated pace. Partnering utilities 
and municipalities are developing internship and cooperative educational opportunities to ensure work-based experiences for students. Trade associations have committed to developing scholarship programs to lessen the financial burden for potential students. In addition, some individual utilities are offering tuition reimbursement for current employees who are pursuing academic degrees or certificate programs. Finally, an educational outreach program that integrates into high school science curricula is being developed. This program is aimed at recruiting young adults into the water and wastewater industry.

\section{Background}

Western Kentucky University (WKU) established the Office of Research and Economic Development in 2005, along with a new Associate Vice President for Research and Economic Development reporting to the University Provost. In addition to consolidating most research and graduate program units under one roof, including the Office of Sponsored Programs, and College of Graduate Studies, the new Office established an office for technology licensing and the WKU Center for Research and Development (The Center). The Center, is co-located with the Central Region Innovation and Commercialization Center (ICC), a regional technology accelerator funded by the Commonwealth of Kentucky and local governments. The ARTP is a Program of Distinction within the Ogden College of Science and Engineering at WKU, emphasizing the integration of undergraduate research, technology development and transfer, and stimulation of entrepreneurship as a mechanism for technology-base regional economic development. The ARTP seeds and facilitates the establishment and growth of multi-disciplinary centers supporting its integrative mission. Several ARTP centers that epitomize the public-private sector vision are located adjacent to the ICC and The Center, providing a catalyst and attractor for technology startups.

The Center for Water Resource Studies (CWRS) is an ARTP Center specializing in the transfer of cutting-edge research into practical water resource management tools. The Center maintains a full staff of qualified technical professionals providing a broad range of services, including: Water and Wastewater Laboratory Analysis; DNA Cloning and Sequencing; Operational Troubleshooting; Specialized Training; Mapping and Modeling; Sampling and Monitoring; Applications Development; Proof-of-Concept and Technology Verification. Center staff act at the interface between university research faculty and graduate and undergraduate students to provide effective translation of ideas into action. The CWRS is organized into three divisions The Water Analysis, Training, Education and Research Services laboratory consortium; the Environmental Informatics and Information Technology division; and the Field Operations and Outreach division. The Water Analysis, Training, Education and Research Services (WATERS) Laboratory is a State certified laboratory specializing in the analysis of drinking water, wastewater and source water for compliance with State and Federal regulations. WATERS provides cost-effective analytical services to water and wastewater treatment facilities, industries, and the general public by using state-of-the-art instruments and experienced staff. The Field Operations and Outreach Division (FOO) is staffed by trained and certified professionals specializing in the collection of field data and on-site training and technical support. This unit provides sub-foot GPS mapping, sample collection, monitoring program development and implementation services under rigorous quality control standards. The division provides mapping and data collection services to municipalities and utilities, in-stream water quality monitoring 
campaigns for watershed planning and Total Maximum Daily Load development, and water, wastewater and stormwater system evaluations. The Environmental Informatics and Information Technology Division (EIIT) employs state-of-the-art Geographic Information System (GIS) technologies and software development environments in the design and development of analysis and visualization applications. The integrated Information Technology (IT) and environmental expertise allows the division to develop real-world applications that meet both the IT demands and the requirements of the water districts within our region. The Division specializes in the integration of web and GIS applications and mapping tools, rules based logic, expert systems and semantic web applications.

The Water \& Wastewater Technician Training Institute (WTTI) is separate workforce development program for water and wastewater operators initiated by the CWRS in 2006. Program content is delivered primarily on-line, simultaneously for both CEU/certification and academic credit towards an associate degree in Water Utilities Management. Students in remote/ rural areas are provided hands-on experiences by local partnering water and wastewater systems, while traditional students at WKU receive their experiential content through WATERS.

\section{Educating the Workforce}

The Partnership for $21^{\text {st }}$ Century Skills has developed a list of Applied Skills that are important

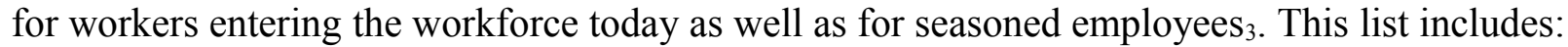

- Oral Communications - the ability to articulate thoughts and ideas clearly and effectively, and have public speaking skills

- Written Communications - the ability to write memos, letters, and complex technical reports clearly and effectively

- Diversity - the ability to learn from and work collaboratively with individuals representing diverse cultures, races, ages, gender, religions, lifestyles, and viewpoints

- Teamwork/Collaboration - the ability to build collaborative relationships with colleagues and customers, and the ability to work with diverse teams, negotiate and manage conflicts

- Critical Thinking and Problem Solving - the ability to exercise sound reasoning and analytical thinking, and to use knowledge, facts, and data to solve workplace problems

- Information Technology Application - the ability to select and use appropriate technology to accomplish a given task and apply computing skills to problem-solving

- Creativity and Innovation - the ability to demonstrate originality and inventiveness in work and to communicate new ideas to others while integrating knowledge from different disciplines

- Leadership - the ability to leverage the strengths of others to achieve common goals and to use interpersonal skills to coach and develop others

- Professional Work Ethic - the ability to demonstrate personal accountability and effective work habits such as punctuality, time and workload management

- Ethics and Social Responsibility - the ability to demonstrate integrity and ethical behavior and to act responsibly with the interests of the larger community in mind

- Lifelong Learning and Self Direction - the ability to continuously acquire new knowledge and skills and to monitor one's own learning needs

Post-secondary education is the key to acquiring the skills needed in todays workforce. As 
regulation in the water and wastewater industry become more stringent, operators face increased expectations in occupational and professional competencies. As a result, operators are required to take on increasing responsibilities and to understand complex regulatory issues. The WTTI Associate Degree program offers focused content, while integrating a balanced core program which allows for a more well-rounded employee and a more professional workforce. Graduates of the program are expected to possess critical-thinking skills with the foresight to recognize potential problems, and be more adaptable to change. Furthermore, the program offers the opportunity for students to enhance their communication skills, both oral and written. The ability to communicate effectively allows for a valuable interface between operators, managers, and engineers, as well as the ability to educate people outside the industry. In addition, the WTTI program holds the potential to make succession planning easier for employers. Entities that encourage operators to pursue an education and that hire educated operators have the ability to prepare and promote quality personnel from within their organization.

\section{Aligning Curriculum with Industry Standards}

As courses are prepared course outlines and content expectations are initially developed from deliberations of the Curriculum committee, which includes representation from all participating trade associations, certifying agencies, representative utilities, etc. This results in a syllabus that is then developed in somewhat greater detail and submitted to the certifying agencies in each state to secure Continuing Education Units. For example, WTTI 200C has been approved for 28 Drinking Water Hours and 36 Wastewater Hours (24 process control, 12 non-process) in Kentucky.

Within the water and wastewater operator industry, the certifying agencies generally substitute years of education for years of work experience on a year-for-year basis. Due to the intensity of the relevant information being taught in the program, proponents of the WTTI program are proposing that the two-year Associate degree be substituted for four-years of work experience.

\section{Rationale for On-line Delivery}

According to the U.S. Department of Education, in 2006-07, there were approximately 11,200 college-level programs that were designed to be completed totally through distance education; 66 percent of these programs were reported as degree programs and the remaining 34 percent were reported as certificate programs. Asynchronous internet-based technologies were cited as the most widely used technology for the instructional delivery of distance education courses; they were used to a large extent in 75 percent and to a moderate extent in 17 percent of the institutions that offered college-level credit-granting distance education courses 6 .

Courses developed for the on-line learning environment offer many advantages over traditional face-to-face courses 8 , including:

- student-centered learning

- writing intensity

- interactive discussions

- self-motivated education

- enriched course material 
- on-demand interaction and support

- immediate feedback

- flexibility

The bulk of this industry's workforce needs are in remote rural areas that, even if within commuting distance to community or technical colleges, rarely amount to sufficient numbers to warrant establishment of degree programs at local institutions. Programs established in urbanized areas, often suffer dwindling enrollment once initial local workforce needs are met. A capacity challenge is therefore meeting a growing workforce demand for an industry who's needs are geographically dispersed and generally insufficient in numbers for sustaining localized academic or vocational programs.

With sufficient interest and enrollment, courses can be delivered in the traditional format, using the online content as supportive course material. In this situation, students will need to be in the same location as the instructor. The most likely scenario is for traditional students local to the WKU campus registering in sufficient numbers to warrant the opening a traditional delivery mode class (if requested). Another option being actively pursued is the establishment of local delivery locations, or points-of-presence. A franchise model is being explored in which content may be provided to participating training/educational establishments. Franchised content can then be replicated for on-line delivery or for traditional in-class instruction. This is likely to occur in urbanized areas with higher population concentrations and active community or technical colleges with access to relevant instructional expertise.

\section{Curriculum Details}

General Education is an integral part of the undergraduate curriculum that both complements and supports the students' preparation in the field of study. General Education classes assist students develop an understanding, appreciation, and acceptance of multiple modes of knowledge (artistic, literacy, philosophical, historical, scientific) through the acquisition, organization, and analysis of specific bodies of knowledge $e_{7}$. In addition, General Education provides a foundation for professional success by engaging the student in critical thinking, rational decision making, and effective communication. The WTTI program includes a set of General Education classes that have been selected to enhance the abilities of the students within the program. The General Education requirements for the WTTI program includes classes from four foundational categories: (22 Academic Hours)

- Category A: Organization and Communication of Ideas (6 Academic Hours)

O ENGL 100: Introduction to College Writing (3 hours)

O SPCH161: Business \& Professional Speaking (3 hours)

- Category B: Humanities (3 Academic Hours) - course to be chosen by student from list including: Literature, Music Appreciation, and Philosophy.

- Category C: Social \& Behavioral Sciences (3 Academic Hours) - course to be chosen by student from list including: Economics, History, Political Science, Psychology, and Sociology.

- Category D: Natural Science \& Mathematics (10 Academic Hours)

O MATH 116: College Algebra (3 hours) 
O BIOL 207: General Microbiology (3 hours)

O CHEM 109: Chemistry for Health Sciences (4 hours)

The Business Technology Core prepares students academically in common business environment skills including management and accounting. These skills may prove invaluable to operators as they advance within their chosen careers. However, often operators are more interested in the science behind the operations of water/wastewater treatment. To address these interests, WTTI is exploring the possibility of offering an Associate of Science degree in Sustainability Studies with a concentration in Water/Wastewater operations that incorporates the current WTTI class offerings.

- Business Technology Core Requirements (21 Academic Hours)

O BT 110C: Basic Accounting I - this course serves as a basic introductory accounting course for students pursuing an associate of arts degree program. It introduces the beginning concepts, principals, and procedures of accounting in a systematic fashion.

O BT 111C: Basic Accounting II - this course builds on what was introduced in BT $100 \mathrm{C}$, further pursuing concepts, principles, and procedures of accounting in a systematic fashion.

O CSCI 145C: Introduction to Computer Systems - in this course the following topics are surveyed: hardware, software, telecommunications, programming languages, software development, a short history of computing, and the computer's impact on society. Projects in word processing, spreadsheets, file management, and BASIC are assigned.

O BT 220C: Principles of Marketing - this course presents the problems of marketing and the ways today's marketers solve them. The course focuses on concepts and principles of theory and practice through the use of practical examples and cases. Studies include market planning, research, strategies, distribution, promotion, pricing, market segmentation, and consumer-oriented marketing.

O BT 250C: Business Communication - this course is a study of the communication processes in business with an emphasis on correct language and grammar. Included is functional correspondence which leads to effective communication, such as letters, reports, memos.

O BT 253C: Business Seminar - this course is designed to explore essential skills that employers want. Includes self-learning, communication and personal effectiveness, problem solving, goal setting, group effectiveness, influencing, managing personal and professional growth, and establishing standards for performance in the workplace. Career development, planning, management, and necessary employability and job search skills will be emphasized.

O BT 256C: Supervisory Management - this course offers a practical approach to understanding and dealing with the problems faced by first-line supervisors.

Utility Management Courses (18 Academic Hours)

UM 101C: Water Utility Management - this course is an overview of water and wastewater utility activities and functions leading to profession designation in utility management

O UM 205C: Water Utility Organization, Regulation and Law - this course offers 
an overview of the organization, structure, and legal aspects of water and wastewater utilities

O UM 215C: Water Utility Finance \& Administration - this course offers an overview of the financial and administrative aspects of water and wastewater utilities

OM 225C: Human Resource Management for Utilities - this course offers an overview of the staffing, compensation, and human resource utilization aspects of water and wastewater utilities

OM 235C: Water Utility Management \& Human Relations - this course is an overview of the management and human relations aspects of water and wastewater utilities including board/manager, employee, public, and other utility relations

O UM 245C: Modern Technology \& Utility Management - this course offers an overview of the essential functions of public drinking water and wastewater utilities focusing on the emerging technologies and evolving legislation that drive quality and quantity issues

\section{Operations Courses (21 Academic Hours)}

- Courses Common to Both the Water and Wastewater Operations Tracks

O WTTI 200C: Water Supply \& Wastewater Control - this course is designed to familiarize the student with water supply and wastewater control. Emphasis is on the engineering aspects of water supply, water distribution, wastewater collection, and wastewater treatment and disposal. Upon completion, students should be able to apply engineering and scientific concepts and principles of water supply and wastewater control.

O WTTI 212C: Water Distribution \& Wastewater Collection - this course is designed to enable students to understand the operation and maintenance of a waterworks distribution system and to familiarize students with the components of wastewater collection systems. Overview of design installation, operation, monitoring, maintenance and repair/rehabilitation of sewer pipelines, pump stations and related facilities.

O WTTI 226C: Water Chemistry - this course is designed to explore basic chemical concepts and principles such as elements, compounds, states of matter and reactions that are applicable to evaluating and regulating water quality and applies them to water and wastewater treatment. Students also examine laboratory techniques, equipment, quality assurance, and record-keeping and reporting.

○ WTTI 222C: Water/Wastewater Instrumentation \& Controls - this course focuses on the basic fundamentals of instrumentation applicable to water and wastewater management. The application, maintenance, and calibration of instruments in water and wastewater systems are emphasized. Upon completion, students should be able to read, calibrate and maintain mechanical, electrical, hydraulic, and pneumatic sensing equipment; and indicating, recording, and control equipment.

\section{- Courses Specific to the Water Operations Track}

O WTTI 210C: Introduction to Water Treatment - this course is designed to train prospective water treatment plant operators and managers in the practical aspects of operating and maintaining water treatment plants, with emphasis on the use of safe practices and procedures. Students will learn how to safely operate and maintain 
coagulation, flocculation, sedimentation, filtration, and disinfection processes. They will also learn how to control tastes and odors in drinking water, control corrosion to meet the requirements of the Lead and Copper Rule, perform basic water laboratory procedures, and solve arithmetic problems commonly associated with water treatment plant operations.

O WTTI 230C: Advanced Water Treatment - this course is a continuation of WTTI $210 \mathrm{C}$ and is designed to train prospective water treatment plant operators and managers in the practical aspects of operating and maintaining water treatment plants, with emphasis on the use of safe practices and procedures. Information is presented on drinking water regulations (including the Safe Drinking Water Act), iron and manganese control, fluoridation, softening, trihalomethanes, demineralization, handling and disposal of process wastes, maintenance, instrumentation, and advanced laboratory procedures. PREREQUISITE: WTTI 210C, WTTI 226C

O WTTI 220C: Calculations \& Hydraulics for Water - this course is designed to provide the student with an understanding of the mathematical principles and practical hydraulic design related to water supply. Topics include the treatment and distribution of water. Study includes solving problems related to treatment systems including hydraulic volumes, dimensional analysis, calculations and chemical dose rates as it relates to water treatment and distribution. Provides information and procedures necessary to predict and manipulate the hydraulics of water transmission. The primary work assignments involve the reading and using of hydraulic principles and then applying them in a real-life case analysis. Upon completion, students should be able to apply principles of mathematics and hydraulic systems to water management practices.

- Courses Specific to the Wastewater Operations Track

O WTTI 211C: Introduction to Wastewater Treatment - this course is designed to train prospective wastewater treatment plant operators and managers in the practical aspects of operating and maintaining wastewater treatment plants, with emphasis on the use of safe practices and procedures. Students will learn how to safely operate and maintain racks, screens, comminutors, sedimentation tanks, trickling filters, rotating biological contactors, package activated sludge plants, oxidation ditches, ponds, and chlorination facilities. Students will also learn how to analyze and solve operational problems and how to perform mathematical calculations relating to wastewater treatment process control.

O WTTI 231C: Advanced Wastewater Treatment - this course is a continuation of WTTI $211 \mathrm{C}$ and is designed to train prospective wastewater treatment plant operators and managers in the practical aspects of operating and maintaining wastewater treatment plants, with emphasis on the use of safe practices and procedures. Topics covered include conventional activated sludge processes, sludge digestion and solids handling, effluent disposal, plant safety and good housekeeping, plant and equipment maintenance, laboratory procedures and chemistry, use of computers of plant operation and maintenance, analysis and presentation of data, and records and report writing. Students will also learn how to analyze and solve operational problems and how to perform the mathematical calculations relating to wastewater treatment process control. PREREQUISITE: WTTI 211C, 226C

O WTTI 221C: Calculations \& Hydraulics for Wastewater \& Stormwater - this 
course is designed to provide the student with an understanding of the mathematical principles and practical hydraulic design related to wastewater and stormwater control. Topics include the collection and treatment of domestic and industrial wastewater, wastewater collection and stormwater. Study includes solving problems related to treatment systems including hydraulic volumes, dimensional analysis, primary and secondary sewage treatment, calculations and chemical dose rates as it relates to wastewater and stormwater technology. Provides information and procedures necessary to predict and manipulate the hydraulics of wastewater and stormwater collection. The primary work assignments involve the reading and using of hydraulic principles and then applying them in a real-life case analysis. Upon completion, students should be able to apply principles of mathematics and hydraulic systems to wastewater and stormwater management practices.

- Additional Courses Proposed as Electives

O WTTI 215C: Electrical and Mechanical Systems - this course deals with pumps, generators, engines, meters, valves, and their related monitoring, safety, as they relate to treatment systems. Topics include an overview of electricity and electronics, hydraulics, and flow monitoring systems. Upon completion, students should be able to explain safety in treatment operations and the safe operations of these systems.

O WTTI 216C: Laboratory Analysis for Water and Wastewater - this course is designed to examine basic fundamentals of laboratory analysis with emphasis on applied chemical and microbiological procedures for water and wastewater plant operators. Upon completion, students should be able to utilize the procedures and techniques used in physical, chemical, bacteriological and biological examination of water/wastewater.

O WTTI 217C: Cross-Connection Control - this course is designed for the study of the administrative and technical procedures required for a cross-connection program including system inspections, hazard evaluation, identification of cross-connection problems and backflow prevention devices, shut-down tests and reclaimed water systems. Upon completion, students should be able to apply the principles of backflow device installation and testing procedures required for the certification testing.

Discussion Forums Among Course Cohorts - The use of discussion boards is an active method of learning, contrasted with the traditional lecture model that is much more passive. As many research studies have shown, active learning is more powerful than passive learning at getting students to learn, retain, and apply course content to novel and practical situations ${ }_{8,9}$. This active engagement with course content gives students an enhanced sense of empowerment, ultimately leading to a more interested, motivated, and participatory student. Discussion forums are used in every WTTI course to encourage active learning and comradery among students.

Class Projects - Embedded within each WTTI class there is at least one class project. The class projects are designed to engage the students in critical thinking about the industry in their geographic area. For example, in the WTTI 200C course, the students trace the water cycle from the local watershed through its treatment for drinking water to their homes. Then they continue the trace through wastewater collection and treatment back to the watershed. To complete the project, students must use on-line tools from the EPA and USGS, as well as direct contact with 
their local water and wastewater treatment, delivery and collection systems.

Co-ops \& Internships - The WTTI Steering Committee is exploring the possibility of requiring at least one 3-Academic Hour Co-Op or Internship experience. The proposed Co-Op or internship must be relevant to WTTI and approved by the WTTI curriculum committee. Experience must be formally evaluated by work supervisor within guidelines specified by curriculum committee. This experience will require coordination between the designated utility (water or wastewater treatment facility, distribution or collection system) and the WTTI education coordinator.

Laboratory Exercises - To accommodate hand-on laboratory experiences for students in select courses such as WTTI 216C and WTTI 226C, the Standard Operating Procedures, methodologies, and theory will be provided in the on-line format, with experimentation taking place at local utilities. WTTI will develop relationships with the local utilities and laboratories with will allow students to perform experiments. For WTTI 216C a smörgåsbord of methods will be available via on-line modules. During the first two weeks of the semester, the students (with guidance from the instructor) will select $\sim 10$ for which local access for hands-on component is reasonably available. The student will then completes selected modules on-line and then execute the procedures at the utility/lab local. The local lab/utility will commits a technician to supervise each experiment and verify execution by student. Students grade will be a combination of online module and procedure report/results sheet.

Mentors - help people assess your strengths and weaknesses, as well as help them to develop skills for success and a long-range career plan. A mentor can foster a sense of belonging within the organization and help navigate the industry's culture and politics. A mentor can provide a fresh perspective -- a new way of looking at a problem or issue ${ }_{10}$. Mentors are utilized within the WTTI program to/as:

- Discussion Forums Participates - forums are topic oriented rather than course oriented allowing continuous asynchronous participation

- Practitioners - Assigned to educators teaching WTTI courses. Also participate in course topic/module specific discussion forums and support educator/instructor in developing class projects and assignments. Must be experienced practitioners.

- Educators - Assigned to practitioners performing instruction. Provide support to practitioner/instructor in conducting course. Must be experienced in on-line delivery and non-traditional students.

- Peers - Peer mentoring occurs within courses with existing operators taking the course working with new recruits and traditional students.

\section{Professional Development of Instructors}

- Faculty Center for Excellence in Teaching - FaCET is a WKU institution. FaCET's purpose is to advance the University community's commitment to excellence in teaching and engagement in learning through exemplary ideas, activities, and resources. FaCET offers an online certificate program entitled Basic Skills for College Teaching. All instructors in the WTTI program will be required to complete this program.

- Faculty Center for Excellence in Teaching - FaCET also offers the Sloan-C Online Teaching Certificate Program. Instructors employed by institutions of high learning in the 
Commonwealth of Kentucky may enroll in this program at no cost. All potential instructors are encouraged to complete this program prior to being approved as an instructor for any WTTI course.

- WKU Office of Distance Learning: Technology Services for Online Teaching - this program offers educators assistance in developing web-based activities for online courses.

- Student to Instructor Concept - to ensure instructors are familiar with course content, potential instructors are required to enroll in the course they plan to instruct prior to being approved as the instructor. For example, the instructor for WTTI 200C for the Spring 2009 semester was enrolled in the class during the Fall 2008 semester.

\section{Recruitment Efforts}

Recruitment of students into the WTTI program is necessary for sustainability of the program. Enrollment in WTTI classes has been low during the first two semesters of offering. Several recruitment measures have been discussed by the Steering Committee. However, with limited funds only a few have been attempted with mixed results. Ideas include:

- General Brochure - a brochure was developed with general WTTI program information

- Curriculum Brochure - a brochure was developed with information on how to get admitted to WKU and the curriculum for the program

- Recruitment Mailer - a brochure was developed and mailed to 7,000 water and wastewater operators in Kentucky and Tennessee in December 2008. The mailer has generated a modest interest in the program among the targeted audience.

- Trade Show Display - a display poster has been developed and is used at industry trade shows to encourage interest in the program.

- Outreach Program - an outreach program is in development. The program will be targeted toward high school juniors and seniors to stimulate interest in the program and bring potential operators into the program. In addition, high school counselors will be contacted to encourage students who do not want a traditional college education to explore the program.

- Tuition/Scholarship Sources:

O Employer Support - is being investigated as point of recruitment. Many employers offer tuition reimbursement to employees who enroll in educational programs, especially when the educational program is targeted to a specific industry.

O One-Stop Career Centers - are being investigated for recruitment. These centers often offer to cover tuition costs for unemployed workers. The programs they cover must be preapproved for the funds. The WTTI Steering Committee is currently working on getting the program pre-approved for tuition payment via the local OSCC.

O Scholarship Funds - tuition scholarships are being investigated through the American Water Works Association as well as via grant funding from various sources.

\section{Market Assessment}


- Licensure - Upon completion of the WTTI program and at least one year of on-thejob experience, operators earn the right to seek licensure within the industry. The license is portable via reciprocity agreements between states within the United States.

- National Demand - Approximately 111,000 people worked in the Water and Wastewater Industry in 2006. According to the U.S. Department of Labor approximately 35,000 jobs will be created in the industry in the next 10 years $_{2}$. In addition, approximately fifty percent of all current operators are expected to retire within the next 7 years 5 . Workforce issues, particularly the impending retirement of Baby Boomers, industry growth and the increased competition for employees, have been in the top five concerns among water professionals surveyed over the past four years 4 .

- International Demand - The demand for water professionals has increased worldwide in the past few years. Organizations such as Boreholes, Inc., Water for People, the United Nations Environment Programme (UNEP), the United Nations Educational, Scientific and Cultural Organization (UNESCO), and the United Nations Development Program (UNDP) are constantly recruiting competent professionals to lead their initiatives and projects around the world. In addition, once projects are completed in the water industry, operators are needed to maintain the facilities and ensure the quality of water and wastewater treatment.

- Regional Demand - The two figures (below) demonstrate the travel distances of selected age groups (based on the 2001 census) to the closest community or technical college in Kentucky. Also overlaid are water and wastewater utilities (number and location) who would be potential employers. While more than $50 \%$ of Kentucky's population lives within 10 miles of a community college, that population is served by less than $25 \%$ of the state's utilities. Conversely, $\sim 50 \%(\sim 1.5 \mathrm{M})$ Kentuckians are served by $\sim 75 \%(\sim 390)$ of the utilities. The workforce needs for these 390 utilities are likely to yield an annual enrollment need of $\sim 50$ jobs dispersed over the entire state. These numbers are insufficient in local quantities to justify program creation at individual community colleges. These statistics underscore the core capacity challenges facing workforce development for a geographically dispersed population coupled with a geographically dispersed job market. The WTTI program has, therefore, a geographical scope that necessarily transcends traditional service area definitions of community/technical colleges and systems thereof. The program is currently being developed and piloted in the rural under-served areas of Kentucky while being extrapolated to Tennessee, without regard for traditional geographic boundaries. Expansion of service meet a nation-wide need is a strategic goal, with partnerships being developed on a case-by-case basis in order to address state-specific regulatory and workforce issues. 


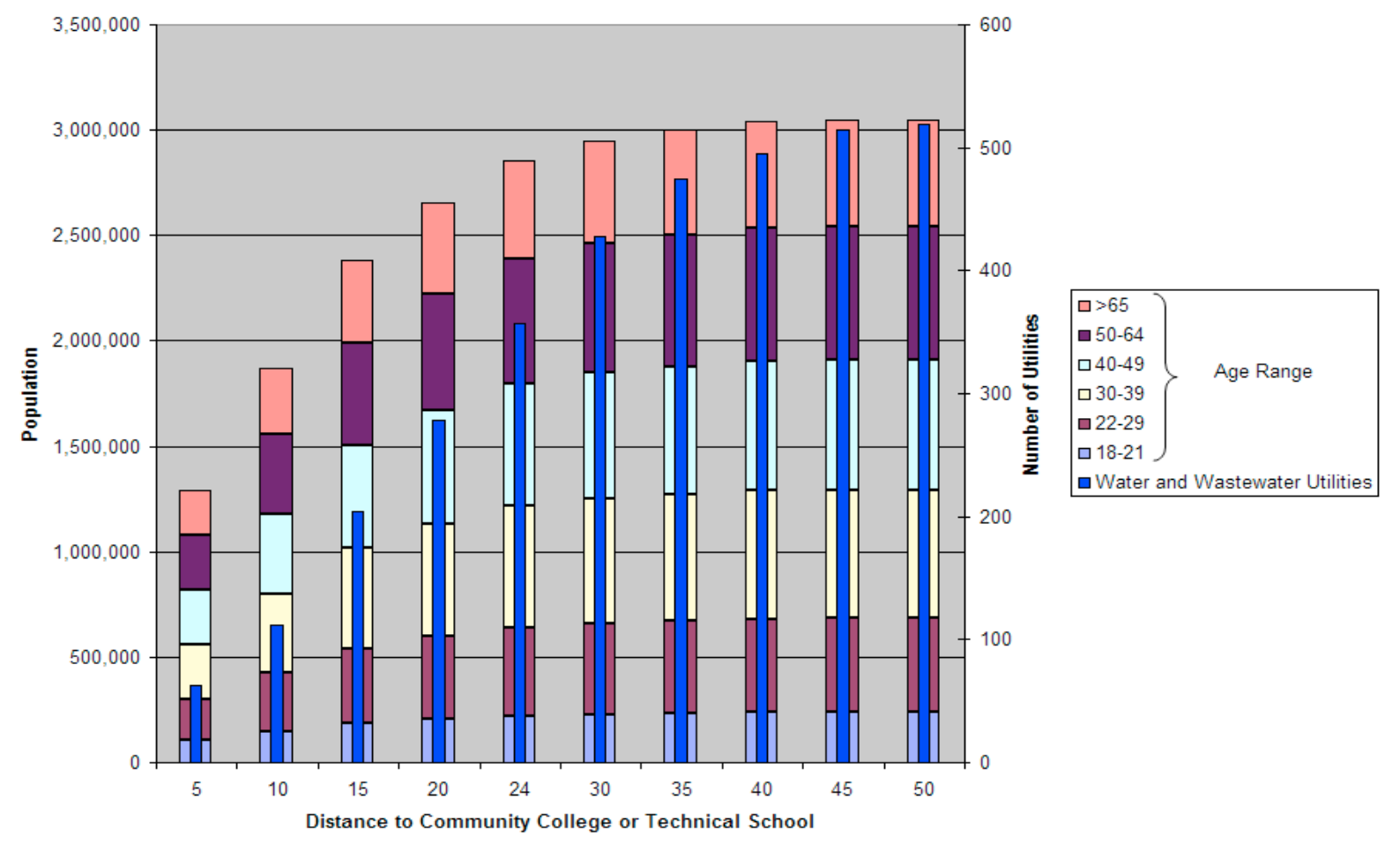

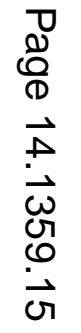




\section{Water and Waterwater Utilites near Community Colleges}

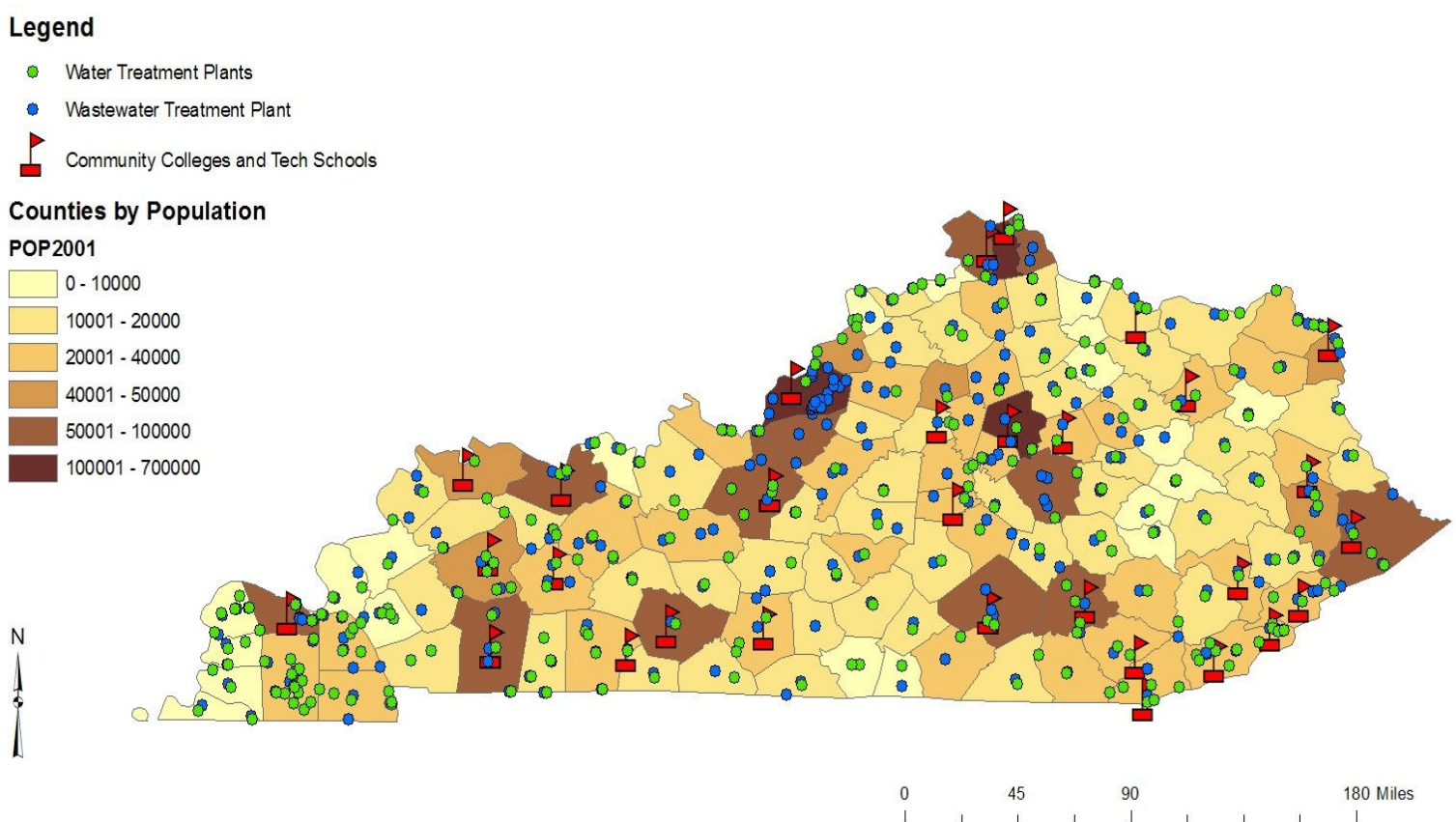

\section{Next Steps}

The WTTI Steering Committee is exploring future possibilities for the WTTI program, including:

- Franchise Model - The WTTI Steering Committee is exploring a Franchise-type model for the delivery of WTTI content in high volume areas. Within this model other institutions of higher learning, such as Jefferson Community \& Technical College, could purchase the course content for local delivery. Another option may be for other institutions to contract with CWRS to provide instruction for the program for their students.

- Incorporation - establishing WTTI as a non-profit organization?

- Accreditation - formalize WTTI as a program accreditation authority?

- Parallel Programs

O Municipal and Urban Stormwater Training (MUST)

○ Energy Sustainability Studies (ESS)

\section{Bibliography}

1. Ernest, ANS, Fattic, JR, and Reid, S. (2008). An Integrated Systematic Approach to Developing a 
Professional Water and Wastewater Workforce. Conference Proceedings, American Society for Engineering Education.

2. Bureau of Labor Statistics, Water and Liquid Waste Treatment Plant and System Operators, 2006.

3. American Water Works Association, AWWA Undertakes New Workforce Initiative, 2008.

4. Runge, J, and Mann, J. (2008). State of the Industry Report 2008: Charting the Course Ahead. Journal of the American Water Works Association.

5. Scalera, P. (2007). The Perfect Storm? The Aging Infrastructure and Work Force. Journal of the American Water Works Association.

6. Parsad, B., and Lewis, L. (2008). Distance Education at Degree-Granting Postsecondary Institutions: 200607 (NCES 2009-044). National Center for Education Statistics, Institute of Education Sciences, U.S. Department of Education. Washington, DC.

7. U.S. Department of Education. National Center for Education Statistics. Vocational Education in the United States: Toward the Year 2000, NCES 2000-029, by Karen Levesque, Doug Lauen, Peter Teitelbaum, Martha Alt, and Sally Librera. Project Officer: Dawn Nelson. Washington, D.C.: 2000.

8. Kassop, M. (2003). Ten ways online education matches, or surpasses, face-to-face learning. The Technology Source.

9. Kubala, T. (1998). Addressing student needs: Teaching on the internet. THE Journal, 25(8), 71-75.

10. Kasprisin, CA., Single, PB., Single, RM., and Muller CB. (2003). Building a Better Bridge: testing etraining to improve e-mentoring programmes in higher education. Mentoring \& Tutoring, 11(1), 67-78. 